\title{
Phytate and phytase: consequences for protein utilisation
}

\author{
P. H. Selle ${ }^{1,2 *}$, V. Ravindran ${ }^{3}$, R. A. Caldwell ${ }^{4}$ and W. L. Bryden ${ }^{1}$ \\ ${ }^{1}$ Department of Animal Science, University of Sydney, Camden, NSW 2570, Australia \\ ${ }^{2}$ BASF Animal Nutrition, 87a St Hilliers Road, Auburn, NSW 2144, Australia \\ ${ }^{3}$ Monogastric Research Centre, Institute of Food, Nutrition and Human Health, \\ Massey University, Palmerston North, New Zealand \\ ${ }^{4}$ Department of Agricultural Chemistry and Soil Science, University of Sydney, Sydney, \\ NSW 2006, Australia
}

The excretion of large amounts of $\mathrm{P}$ in effluent from intensive pig and poultry units is indicative of the poor availability of phytate-bound $\mathrm{P}$ in plant-derived feed ingredients. This environmental problem prompted the development and acceptance of microbial phytase feed enzymes for single-stomached animals. Their introduction led to an increasing recognition that phytate may have adverse effects on protein utilisation in addition to $P$. Consequently, the nutritional relevance of protein-phytate interactions for pigs and poultry is considered in the present review. Since the current understanding of the effects of protein-phytate interactions comes mainly from responses obtained to added phytase, literature on the influence of microbial phytases on amino acid digestibility and utilisation is summarised, followed by a discussion of possible mechanisms contributing to the negative effects of phytate. However, the rationale for the protein responses to added phytase remains largely speculative, and several modes of action are probably involved. It may be that the release of protein from protein-phytate complexes occurring naturally in feed ingredients, the prevention of formation of binary and ternary protein-phytate complexes within the gut, the alleviation of the negative impact of phytate on digestive enzymes and the reduction in endogenous amino acid losses are all contributing factors. A better understanding of the mechanisms of protein-phytate interactions and the modes of action of exogenous phytase enzymes is clearly desirable. Studies are also needed to identify and quantify the factors that contribute to the variable amino acid responses to added phytase. It appears that the relative solubilities of phytate salts and proteins from different feed ingredients and their effects on the extent of protein-phytate complex formation, coupled with variations in the effectiveness of phytase in different dietary contexts, may be the major factors responsible.

Amino-acid digestibility: Phytase: Phytate

*Corresponding author: Peter Selle, fax +61 29735 5404, email: sellep@basf-australia.com.au 
The capacity of phytic acid to bind minerals reduces the digestion and absorption of $\mathrm{P}, \mathrm{Ca}, \mathrm{Zn}$ and $\mathrm{Fe}$ from plant-derived ingredients by single-stomached animals. Bioavailability of nutrients, especially minerals, has received much attention since the discovery of phytic acid about 150 years ago. In animal nutrition the interest in phytic acid, or phytate, has centred around its effect on $\mathrm{P}$ utilisation. By reducing $\mathrm{P}$ availability, phytate contributes to environmental pollution by the loss of undigested $\mathrm{P}$ in effluent from pig and poultry units, as reviewed by Kornegay (1996a). The aetiological role of phytate in parakeratosis of swine, a manifestation of $\mathrm{Zn}$ deficiency (Oberleas et al. 1962), is another illustration of the negative effects of phytate.

In relation to mineral availability in human subjects the consequences of the dietary intake of phytate have caused some controversy. Some researchers argue that there are risks of $\mathrm{Zn}$ and Ca deficiencies from high-phytate diets (Sandstead, 1992), while other researchers suggest such claims are exaggerated (Walker \& Walker, 1992). However, knowledge gained in developing methods of extracting phytate for the manufacture of protein isolates with reduced phytate content for human consumption has increased the appreciation of protein-phytate interactions, as they interfere with phytate extraction procedures (Cheryan, 1980).

Paradoxically, phytate may have some benefits in human nutrition, particularly in relation to carcinogenesis as it has been shown to have protective effects against colonic cancers (Graf $\&$ Eaton, 1993). The complexing of Fe by phytate may reduce the Fe-catalysed production of free radicals in the colon. In pigs it has been shown that phytate derived from maize and soyabean meal was protective against lipid peroxidation in the colon associated with Fe (Porres et al. 1999). High-fibre diets contain substantial phytate concentrations, and this factor may partially explain the epidemiological association of high-fibre diets with lower incidences of certain cancers (Harland \& Morris, 1995). Phytate and its lower esters, and inositol, have a function in secondary messenger transduction systems. Recent evidence suggests that signaltransduction pathways, cell-cycle regulatory genes, differentiation genes, oncogenes and perhaps tumour-suppressor genes are involved in the anti-neoplastic effects of phytate (Shamsuddin, 1999).

The present review considers the relevance of protein-phytate interactions to pigs and poultry. Since responses to phytase feed enzymes provide most information about these interactions, the present paper will review the effects of microbial phytase on amino acid digestibility and utilisation. Consideration is given to the possible mechanisms underlying the adverse effects of protein-phytate interactions and the factors that contribute to variation in the protein responses to added phytase.

The existence of protein-phytate complexes was probably first observed in extracts from cottonseed (Jones \& Csonka, 1925). Rojas \& Scott (1969) suggested that these complexes have adverse effects in poultry nutrition. It is accepted that phytate interacts with protein to form two different complexes depending on $\mathrm{pH}$ (Cosgrove, 1966; Anderson, 1985). Binary proteinphytate complexes are present at acidic $\mathrm{pH}$, and ternary protein-mineral-phytate complexes are formed via a cationic bridge as $\mathrm{pH}$ approaches neutrality. Theoretically, the hydrolysis of phytate releases phytate-bound proteins and $\mathrm{P}$ for utilisation by the animal. Indirect evidence in support of this theory comes from a number of growth trials where performance responses to added phytase, unrelated to increased $\mathrm{P}$ availability, have been observed in pigs (Beers \& Jongbloed, 1992; Campbell et al. 1995) and poultry (Simons et al. 1990; Cabahug et al. 1999). While the primary role of phytase feed enzymes was to increase the availability of phytatebound $\mathrm{P}$, they have provided new insights into the anti-nutritive properties of phytate. The interaction of phytate with proteins may have considerable practical and economical significance in animal nutrition, and is the focus of the present review. 


\section{Phytate and phytase}

The chemistry, occurrence and anti-nutritive effects of phytate have been reviewed in detail by a number of authors, including Nelson (1967), Cheryan (1980), Maga (1982), Reddy et al. (1982), Wise (1983), and more recently by Torre et al. (1991) and Ravindran et al. (1995). Monographs on phytic acid and inositol phosphates have been published by Cosgrove (1980) and Graf (1986). Salient properties of phytate and phytase are considered briefly as background information.

\section{Phytate}

Phytic acid (myo-inositol hexaphosphoric acid) is present in grains and seeds as a mixed salt, phytate, mainly involving $\mathrm{Mg}, \mathrm{Ca}, \mathrm{Na}$ and $\mathrm{K}$. The aleurone layer is the major site of phytate deposition in most cereals, whereas it is distributed uniformly throughout the kernels in dicotyledonous seeds, including oilseeds and grain legumes (Lott, 1984). Phytate salts, which are sometimes called phytin, function as sources of phosphate, myo-inositol and cations during seed germination (Reddy et al. 1982). The $\mathrm{P}$ concentration of phytic acid is $282 \mathrm{~g} / \mathrm{kg}$ and phytate-bound $\mathrm{P}$ constitutes most of the $\mathrm{P}$ in plant seeds. Due to the common usage of plantderived ingredients, phytate-P concentrations range from 2.5 to $4.0 \mathrm{~g} / \mathrm{kg}$ in typical poultry rations (Ravindran, 1995), and the span may be greater for pigs. The phytate-P content and intrinsic phytase activity of feed ingredients were recently reviewed (Weremko et al. 1997) and data generated from feedstuffs sourced in Australia are presented in Table 1.

The adverse effects of phytate on the availability of $\mathrm{P}$ and other nutrients have been recognised for many years (Cosgrove, 1966). For nutrients other than $\mathrm{P}$, these effects are a consequence of the chelating capacity of phytate. As a result of this chelating capacity, phytate may form complexes with minerals, starch and, as illustrated in Fig. 1, protein. Phytic acid is a moderately strong acid with five to six $\mathrm{H}^{+}$dissociating with $\mathrm{pK}$ of about $1 \cdot 5$, two to three $\mathrm{H}^{+}$ dissociating with $\mathrm{pK}$ between 4 and 6 and four $\mathrm{H}^{+}$dissociating with pK greater than 8 (Martin \& Evans, 1986), which approximates to a net charge on the phytate ion of -3 at $\mathrm{pH} 1.5 \mathrm{rising}$ to -8 at $\mathrm{pH} 7 \cdot 5$. The large negative charge may be counterbalanced by positively charged

Table 1. Total phosphorus and phytate-phosphorus contents and intrinsic phytase activities of common feed ingredients sourced in Australia*

\begin{tabular}{|c|c|c|c|c|c|}
\hline Feed ingredient & $\begin{array}{l}\text { No. of } \\
\text { samples }\end{array}$ & $\begin{array}{l}\text { Total P } \\
(\mathrm{g} / \mathrm{kg})\end{array}$ & $\begin{array}{c}\text { Phytate-P } \\
\text { (g/kg) }\end{array}$ & $\begin{array}{c}\text { Phytate-P/P } \\
\times 100(\%)\end{array}$ & $\begin{array}{l}\text { Phytase activity } \\
(\text { FTU/kg) } \dagger\end{array}$ \\
\hline \multicolumn{6}{|l|}{ Cereals } \\
\hline Barley & 4 & $2 \cdot 60$ & 1.69 & 65 & 416 \\
\hline Maize & 2 & 2.40 & 2.05 & 85 & 25 \\
\hline Sorghum & 13 & 2.92 & 2.42 & 83 & 26 \\
\hline Wheat & 30 & 2.85 & 2.08 & 73 & 471 \\
\hline \multicolumn{6}{|l|}{ Oilseed meals } \\
\hline Rapeseed & 14 & 8.80 & 6.65 & 76 & $<10$ \\
\hline Cottonseed & 7 & 11.46 & 9.04 & 79 & 15 \\
\hline Soyabean & 17 & $6 \cdot 71$ & 4.52 & 67 & 42 \\
\hline Sunflower & 2 & 9.03 & 7.48 & 83 & $<10$ \\
\hline \multicolumn{6}{|l|}{ Others } \\
\hline Rice bran & 15 & 17.59 & 15.93 & 91 & 127 \\
\hline Wheat by-products & 6 & 7.96 & 6.85 & 86 & 2126 \\
\hline
\end{tabular}

FTU, phytase activity units, where 1 FTU is the amount of enzyme that liberates $1 \mu$ mol inorganic orthophosphate/min from $0.0051 \mathrm{~mol}$ sodium phytate/l at $\mathrm{pH} 5.5$ and $37^{\circ} \mathrm{C}$.

* Data supplied by Mr A.R. Walker, BRI Australia Ltd, North Ryde, NSW, Australia.

†Units phytase activity (FTU)/kg feed ingredient tested. 


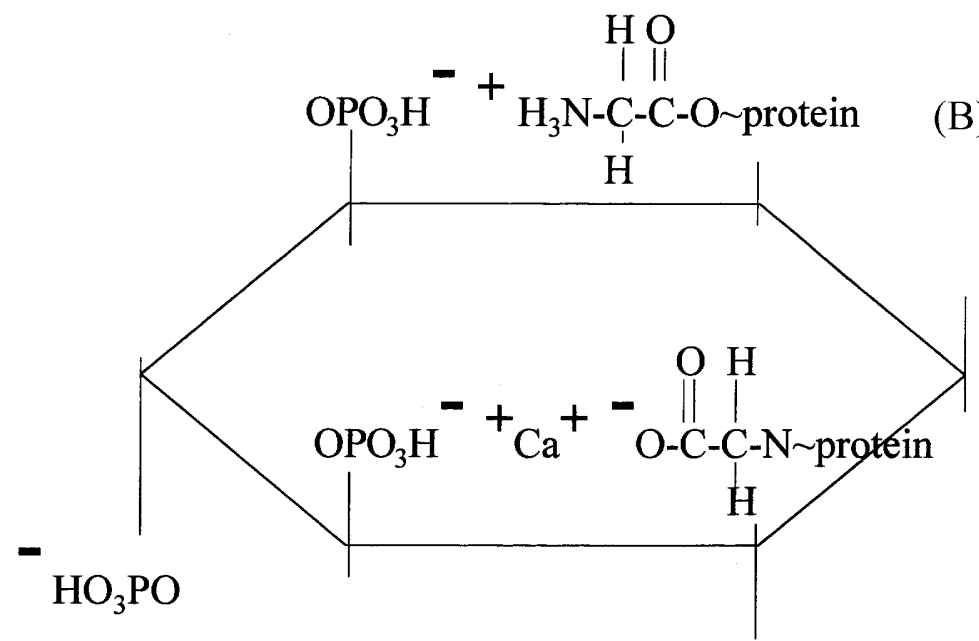

(B)

Fig. 1. Binary (B) and ternary $(T)$ protein-phytate complexes. (After Anderson, 1985.)

molecules, including mineral cations, low-molecular-weight carbo-cations and proteins at $\mathrm{pH}$ values less than their isoelectric points. The complexing is possible within a phosphate group or between two phosphate groups on either the same or different phytic acid molecules (Cheryan, 1980). The interaction of the phytate anion with a counter-cation may result in precipitation of the cation-phytate complex, although this process is dependent on the relative amount of cation, its valency and the $\mathrm{pH}$ (Nolan et al. 1987). Most chelates with divalent mineral cations are soluble at $\mathrm{pH}<3 \cdot 5$, with maximum insolubility occurring between $\mathrm{pH} 4$ and 7 . Chelates with monovalent mineral cations such as $\mathrm{Na}$ and $\mathrm{K}$ are soluble over the full $\mathrm{pH}$ spectrum.

\section{Phytase}

Phytate-bound $\mathrm{P}$ is poorly utilised by single-stomached animals, due to insufficient phytase activity under normal dietary conditions (Taylor, 1965; Nelson, 1967; Ravindran et al. 1995; Fandrejewski et al. 1997). Phytase (myo-inositol hexaphosphate phosphohydrolase) enzymes of endogenous or exogenous origin must hydrolyse phytate for phytate-P to be utilised. Phytases have the capacity to dephosphorylate phytate in a step-wise manner to a series of lower inositol phosphate esters (myo-inositol pentaphosphate to myo-inositol monophosphate) and ultimately, in theory at least, to inositol and inorganic P. Two kinds of phytases have been recognised that initiate the hydrolysis of phytate at either the 3- or the 6-position of the inositol ring. Usually, but not invariably, microbial phytase falls into the first category and plant phytase the second category (Turk et al. 2000).

The assay for phytase activity is based on the release of inorganic phosphate from the hydrolysis of sodium phytate by phytase (Engelen et al. 1994). Enzyme activity is expressed in activity units (FTU) where 1 FTU is the amount of enzyme that liberates $1 \mu$ mol inorganic orthophosphate/min from $0.0051 \mathrm{~mol}$ sodium phytate/l at $\mathrm{pH} 5.5$ and a temperature of $37^{\circ} \mathrm{C}$.

In the gastrointestinal tract phytase activity is derived from the intestinal mucosa and gut microflora (Griener et al. 1993). Some reports suggest that intestinal phytases contribute to phytate-P digestibility in pigs (Hu et al. 1996) and poultry (Maenz \& Classen, 1998), but it is generally assumed that the activity of mucosal phytase is of little consequence. Hindgut fer- 
mentation, especially in pigs, has the capacity to hydrolyse phytate, but this process is unlikely to be of any nutritional value to the animal. Certain cereals, including wheat, rye, triticale and barley, possess intrinsic phytase activity (Weremko et al. 1997), but activity in most feed ingredients is negligible. These cereals and their by-products can be employed in practical diets as a source of exogenous phytase to improve P retention (Barrier-Guillot et al. 1996), but effectiveness appears variable. This variability is probably related to the effects of $\mathrm{pH}$ in the upper digestive tract on plant phytase activity (Eeckhout \& de Paepe, 1991; Phillippy, 1999). Importantly, plant phytase is heat labile and unlikely to withstand pelleting temperatures during feed manufacture (Jongbloed \& Kemme, 1990).

The quest for exogenous microbial phytase to dephosphorylate phytate is not new (Nelson et al. 1968), and the characteristics and the development of phytase feed enzymes have been thoroughly reviewed (Wodzinski \& Ullah, 1996). Although high production costs of microbial phytase have prevented its use in the past, recombinant DNA technology has generated new possibilities of improving $\mathrm{P}$ utilisation and lowering $\mathrm{P}$ excretion in pigs and poultry. Interest in this area has been intense, as there has been a proliferation of publications since the initial report by Simons et al. (1990) and the commercial introduction of a phytase feed enzyme in The Netherlands the following year (Lenis \& Jongbloed, 1999). Microbial phytase is well suited to feed application as the $\mathrm{pH}$ optimum is low and compatible with gastric conditions where phytate is most soluble (Campbell \& Bedford, 1992). Thermostability problems can be avoided by the liquid application of phytase to feed following heat treatment. The capacity of microbial phytase to release phytate-bound $\mathrm{P}$ for utilisation by single-stomached animals is now well documented. Reported improvements in $\mathrm{P}$ availability are generally in the range of $20-45 \%$. The amount of phytate-P released is influenced by the level and source of added phytase and substrate coupled with dietary levels of non-phytate-P, $\mathrm{Ca}$, cholecalciferol and Ca:P (Ravindran et al. 1995).

\section{Microbial phytase and the utilisation of amino acids and protein}

The earliest report indicating that microbial phytase has a positive effect on protein availability in poultry was by van der Klis \& Versteegh (1991). They found that the addition of phytase to layer-hen diets resulted in small but significant improvements in the apparent ileal digestibility of N. Concurrently, a group led by the late Ted Batterham generated amino acid digestibility and protein utilisation data in pigs (Officer \& Batterham 1992a,b; Barnett et al. 1993; Ketaren et al. 1993). For example, Barnett et al. (1993) found that phytase supplementation of conventional weaner diets significantly $(P<0.05)$ increased the digestibility of $\mathrm{N}$ (from 0.66 to $0 \cdot 71$ ) and tended to increase both lysine digestibility and protein retention.

During the last decade, a number of groups in Australia, Europe and North America have investigated the effects of phytase supplementation on the digestibility of amino acids and $\mathrm{N}$ in pig and poultry diets. These studies, and those related to protein utilisation, are reviewed (where 'digestibility' is referred to, it is used synonymously with 'apparent ileal digestibility'). The apparent ileal digestibility assay has become the favoured technique for estimating protein availability, largely because the values apply directly to the bird or animal, and all amino acids can be assessed in the one assay. It is assumed that digestibility is likely to be the rate-limiting step in the availability of amino acids (Ravindran \& Bryden, 1999). Only assessments of amino acid digestibility at the ileal level are included in the present review; total tract assessments are excluded because of the modifying influence of microbial fermentation on protein in pigs (Sauer \& Ozimek, 1986) and poultry (Ravindran et al. 1999b) in the hindgut. 


\section{Digestibility of amino acids in poultry}

Four studies have assessed phytase supplementation of typical North American maizesoyabean broiler diets on the digestibility of amino acids and are summarised in Table 2. Kornegay (1996b) examined the influence of three dietary levels of protein $(170,200$ and $230 \mathrm{~g} /$ $\mathrm{kg}$ ) and four levels of phytase $(0,250,500$ and $750 \mathrm{FTU} / \mathrm{kg}$ diet $)$ on the digestibility of $\mathrm{N}$ and amino acids in 4-week-old broilers. Phytase linearly increased the digestibility of all amino acids, except methionine, at all dietary protein levels. More pronounced responses were observed in a second study (Kornegay et al. 1999) when phytase was added to amino aciddeficient broiler finisher diets. Addition of graded levels of phytase (0,150, 300 and 450 FTU/ $\mathrm{kg}$ diet) linearly increased the digestibility of amino acids, with the exceptions of methionine and proline. Namkung \& Leeson (1999) found that phytase significantly increased the digestibility of valine and isoleucine $(P<0.05)$ and total amino acids $(P<0.01)$ in maizesoyabean diets for broilers. However, phytase did not increase the digestibility of amino acids in a modified finisher diet with high inherent digestibility coefficients (Zhang X et al. 1999).

In additional North American studies Sebastian et al. (1997) reported that phytase supplementation improved the digestibility of most amino acids in a maize-soyabean-meal diet fed to female broilers, whereas phytase tended to have negative effects in male chicks. The reasons for this 'apparent' sex effect are unclear, but the results from other published studies where male broilers were used contradict these findings. In mature birds Biehl \& Baker (1997) reported that adding $1200 \mathrm{FTU}$ phytase/kg increased true amino acid digestibility by $2 \%$ with caecectomised roosters. Zhang ZB et al. (1999) in studies with adult roosters reported that added phytase caused significant improvements $(P<0.05)$ in the digestibility of $\mathrm{N}$ and most amino acids in barley, rapeseed meal and a barley-rapeseed-meal blend. The magnitude of improvement was greater for threonine, cystine, lysine, arginine and serine.

Results from three Australian broiler studies are summarised in Table 3. Ravindran et al. (2000a) examined the effects of phytase supplementation on the digestibility of amino acids of broiler diets based on a wheat-sorghum blend with two levels of available P. Phytase increased the digestibility of the amino acids assessed, but the effects were more pronounced with the lower-P diet; indeed, significant interactions between phytase and $\mathrm{P}$ levels were recorded for histidine $(P<0.01)$, arginine, leucine, threonine and valine $(P<0.05)$. Since the difference between the two diets was $12 \mathrm{~g}$ dicalcium phosphate $/ \mathrm{kg}$, the implication is that inorganic $\mathrm{Ca}$ and/or P limited the response to phytase.

Phytase supplementation of a diet based on casein and a 'low-metabolizable energy' wheat (Mollah et al. 1983) significantly increased $(P<0.05)$ the overall digestibility of fourteen amino acids by $5.0 \%$ (from 0.80 to 0.84 ), lysine by $4.5 \%$, and threonine by $11.4 \%$, (Ravindran et al. 1999 c). A predominantly xylanase feed enzyme enhanced the digestibility of amino acids to a very similar extent. However, phytase and xylanase in combination were more effective than the individual enzymes and, arguably, simultaneous use had synergistic effects for certain amino acids including arginine, histidine, leucine, lysine and phenylalanine. Given the complexities of the substrates in wheat, greater responses would be expected from dietary supplementation with a broad spectrum of exogenous enzyme activities. Access of the two enzymes to their respective substrates may be facilitated in a reciprocal fashion, as approximately three-quarters of phytate in wheat occurs in the soluble-fibre fraction (Frolich \& Asp, 1985). Similar additive effects between microbial phytases and xylanases have been reported in broiler chickens with respect to growth performance and bone mineralisation (Zyla et al. 1999).

Supplementation of a lysine-deficient broiler diet based on a wheat-sorghum blend with graded levels of phytase $(0-1000 \mathrm{FTU} / \mathrm{kg}$ diet $)$ had significant linear effects $(P<0.001)$ on the 
Phytate and phytase and protein utilization

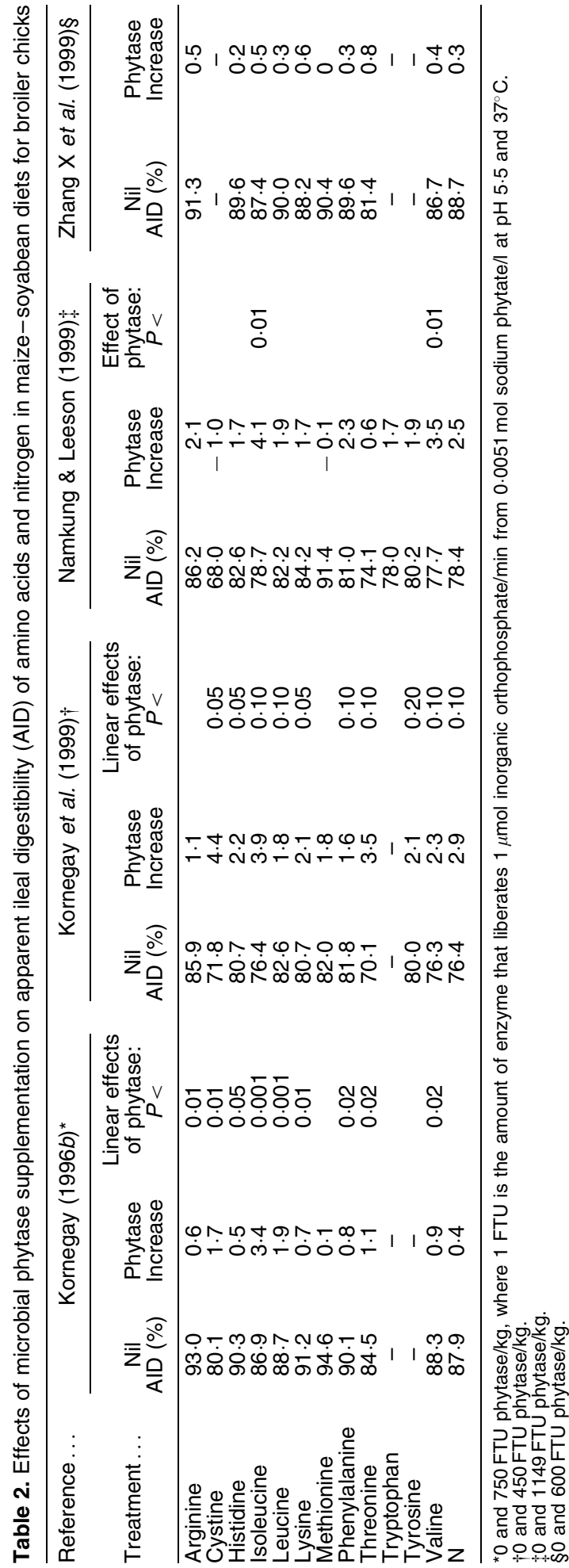


P. H. Selle et al.

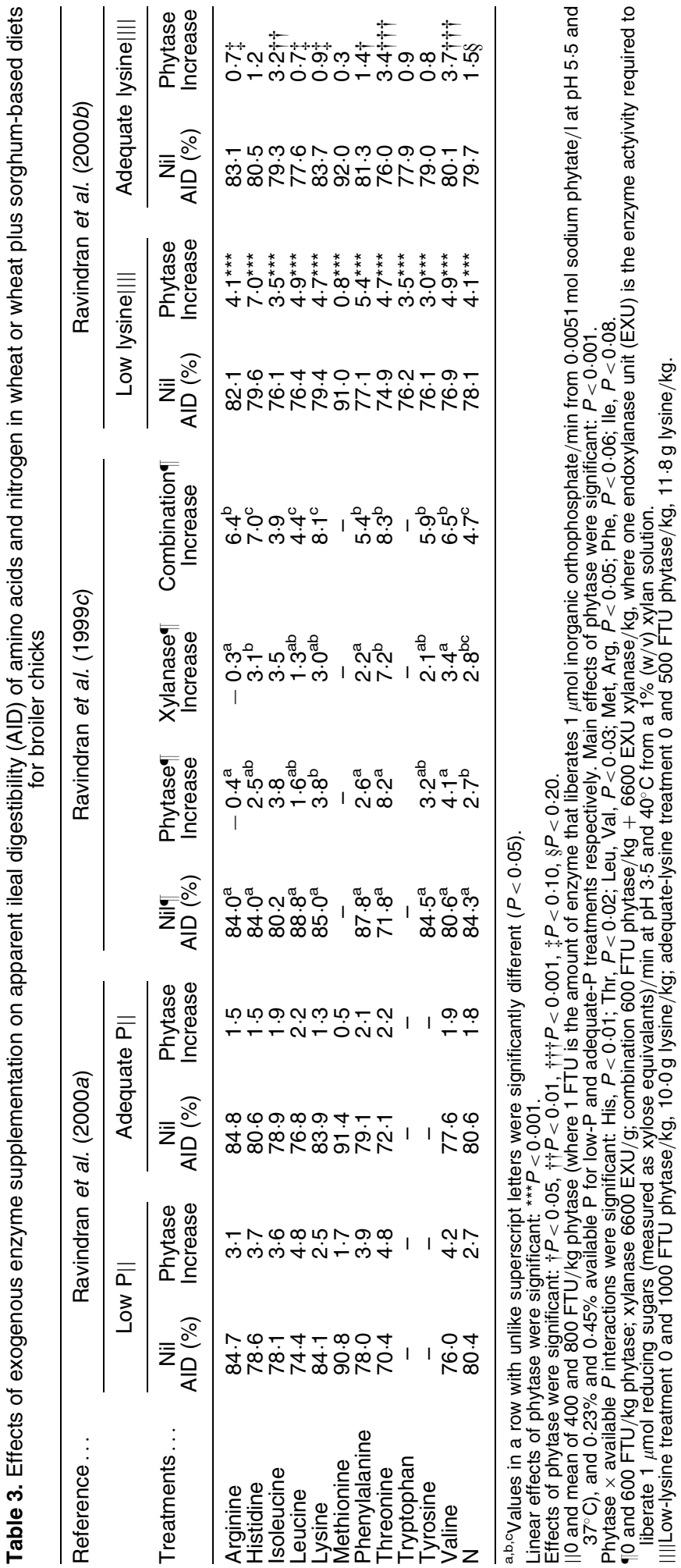


digestibility of all amino acids assessed (Ravindran et al. 2000b). At $1000 \mathrm{FTU} / \mathrm{kg}$ diet phytase increased average amino acid digestibility by $5.0 \%$. Phytase supplementation at $500 \mathrm{FTU} / \mathrm{kg}$ lysine-adequate diet also improved the digestibility of most amino acids, but the increases were less pronounced.

The effects of microbial phytase supplementation on the digestibility of amino acids of nine individual feed ingredients determined by Ravindran et al. (1999a) are shown in Table 4. Interestingly, improvements in amino acid digestibility generated by phytase were noticeably greater in wheat than maize, and the implications of these improvements are discussed later (see p. 272). Increases in the amino acid digestibility of four protein meals following phytase supplementation were similar (V Ravindran, PH Selle, G Ravindran, PCH Morel, AK Kies and WL Bryden, unpublished results).

In turkeys the effects of phytase addition to maize-soyabean diets have also been determined. Yi et al. (1996) found that microbial phytase (750 FTU/kg) significantly improved $(P<0.05-P<0.001)$ true and apparent ileal digestibility of $\mathrm{N}$ and amino acids for 29 -d-old poults. However, the responses to phytase were affected by dietary levels of both non-phytate-P $(4.5$ and $6.0 \mathrm{~g} / \mathrm{kg}$ ) and protein $(225$ and $280 \mathrm{~g} / \mathrm{kg})$. Ledoux et al. (1999) fed turkey poults a maize-soyabean meal diet formulated on an ideal protein basis and supplemented with four levels of microbial phytase (0, 200, 400 and 600 FTU/kg diet). Supplemental phytase linearly increased the digestibilities of lysine, phenylalanine, leucine, isoleucine, methionine, cystine, tryptophan and $\mathrm{N}$.

\section{Digestibility of amino acids in pigs}

There are fewer published data on the effects of phytase addition on the ileal digestibility of amino acids in pigs than poultry. The available literature for the key amino acids is summarised in Table 5. Officer \& Batterham $(1992 a, b)$ determined the effects of phytase supplementation on the digestibility of amino acids of linola meal, a low-linolenic acid variant of linseed, using a slaughter technique. The digestibility of the amino acids in linola meal was very poor and the addition of phytase numerically improved the average digestibility of ten amino acids by $14 \%$

Table 4. Effects of phytase (1200 FTU/kg) on apparent ileal digestibility (\%) of amino acids and $\mathrm{N}$ (\% improvement) by broiler chicks of individual feed ingredients, and phytate-phosphorus content ( $\mathrm{g} / \mathrm{kg}$ ) and intrinsic phytase activity (FTU/kg) of the feed ingredients (from Ravindran et al. 1999a)

\begin{tabular}{|c|c|c|c|c|c|c|c|c|c|}
\hline $\begin{array}{l}\text { Feed } \\
\text { ingredient }\end{array}$ & Maize & Sorghum & Wheat & $\begin{array}{l}\text { Soyabean } \\
\text { meal }\end{array}$ & $\begin{array}{c}\text { Rapeseed } \\
\text { meal }\end{array}$ & $\begin{array}{c}\text { Cottonseed } \\
\text { meal }\end{array}$ & $\begin{array}{c}\text { Sunflower } \\
\text { meal }\end{array}$ & $\begin{array}{l}\text { Wheat } \\
\text { middlings }\end{array}$ & $\begin{array}{c}\text { Rice } \\
\text { polishings }\end{array}$ \\
\hline \multicolumn{10}{|l|}{ Amino acid } \\
\hline Arginine & 3.7 & 6.5 & $10 \cdot 3$ & $2 \cdot 3$ & 1.9 & 2.9 & $2 \cdot 0$ & 1.9 & $4 \cdot 0$ \\
\hline Histidine & 2.9 & 7.0 & 9.5 & 4.2 & $2 \cdot 1$ & 3.9 & $5 \cdot 3$ & $3 \cdot 1$ & 7.0 \\
\hline Isoleucine & 2.7 & $5 \cdot 8$ & $6 \cdot 6$ & 3.4 & $3 \cdot 1$ & $7 \cdot 0$ & 4.4 & 3.3 & 7.2 \\
\hline Leucine & 1.0 & 6.4 & 6.4 & 2.5 & $2 \cdot 8$ & $5 \cdot 8$ & 4.4 & $3 \cdot 1$ & $8 \cdot 3$ \\
\hline Lysine & 3.4 & 3.7 & 10.9 & 4.0 & 0.9 & 4.7 & 5.7 & 2.4 & $5 \cdot 1$ \\
\hline Phenylalanine & $2 \cdot 1$ & 6.5 & $6 \cdot 3$ & 4.0 & 2.6 & 3.9 & 4.4 & 3.0 & $9 \cdot 2$ \\
\hline Threonine & $6 \cdot 7$ & $8 \cdot 8$ & $15 \cdot 7$ & $8 \cdot 0$ & $4 \cdot 1$ & 6.9 & $5 \cdot 1$ & $6 \cdot 1$ & $7 \cdot 1$ \\
\hline Tyrosine & 2.7 & 8.8 & 11.1 & 3.5 & 2.3 & 3.4 & 4.3 & 5.5 & $10 \cdot 4$ \\
\hline Valine & $4 \cdot 1$ & 6.5 & $8 \cdot 8$ & 3.4 & 3.4 & $5 \cdot 6$ & 4.8 & 3.6 & 5.6 \\
\hline $\mathrm{N}$ & 4.2 & 6.9 & $7 \cdot 3$ & $6 \cdot 1$ & $3 \cdot 2$ & 3.8 & 3.8 & 3.7 & $9 \cdot 2$ \\
\hline Overall mean* & 3.4 & 6.5 & $9 \cdot 0$ & 4.2 & $2 \cdot 7$ & 4.8 & 4.8 & 3.7 & 7.5 \\
\hline Phytate-P & $2 \cdot 1$ & $2 \cdot 1$ & 1.6 & $4 \cdot \overline{7}$ & 7.4 & 9.3 & 7.7 & 7.8 & $15 \cdot 5$ \\
\hline Phytase & 10 & $<10$ & 340 & 30 & $<10$ & $<10$ & $<10$ & 2500 & 70 \\
\hline
\end{tabular}

FTU, phytase activity units, where 1 FTU is the amount of enzyme that liberates $1 \mu \mathrm{mol}$ inorganic orthophosphate/min from $0.0051 \mathrm{~mol}$ sodium phytate/l at $\mathrm{pH} 5.5$ and $37^{\circ} \mathrm{C}$.

* Phytase increased the overall mean digestibility of fourteen amino acids $(P<0.05-P<0.01)$ from each of the nine feed ingredients; the additional amino acids included alanine, aspartic acid, glycine, glutamic acid and serine. 
(from 0.63 to 0.72$)$, but significant increases $(P<0.05)$ were observed only for lysine, histidine and $\mathrm{N}$.

Two studies have been published from The Netherlands in which cannulation procedures were adopted. Phytase was included in typical grower diets (tapioca, maize, barley, soyabean and sunflower meals) with wide values for Ca:P (2.03:1; Mroz et al. 1994). Enzyme addition significantly improved $(P<0.01)$ the digestibility of methionine and arginine but, overall, the enzyme had little effect on amino acid digestibility, which seems inconsistent with the significant increase $(P<0.01)$ in $\mathrm{N}$ retention (from 20.4 to $25.9 \mathrm{~g} / \mathrm{d})$ recorded in the study. In the second evaluation (Mroz et al. 1995a) phytase supplementation of maize-soyabean diets with lower protein contents and narrower values for $\mathrm{Ca}: \mathrm{P}(1 \cdot 77: 1)$ significantly increased the digestibility of threonine $(P<0 \cdot 01)$, isoleucine, lysine, tryptophan and six non-essential amino acids $(P<0 \cdot 05)$.

A major difference in the studies described earlier was the method of collecting ileal digesta. Kornegay et al. (1998) determined the effects of phytase supplementation on the digestibility of amino acids by sampling ileal digesta from both cannulated and slaughtered pigs. In the cannulated pigs phytase had significant linear effects $(P<0.05)$ on the digestibility of four key amino acids but, in contrast, significant linear effects $(P<0.05-P<0.001)$ were observed for the digestibility of ten amino acids with the slaughter technique. The amino acid digestibilities in the control diets were similar, irrespective of the method of determination. However, phytase (500 FTU/kg) increased the average digestibility of amino acids by $3.5 \%$ in cannulated pigs, as opposed to an average increase of $10.7 \%$ with slaughtered pigs.

In the Kornegay et al. (1998) study phytase improved growth rates of finisher pigs by $10.1 \%$; this level was comparable with the $12.0 \%$ improvement resulting from increasing dietary protein from 100 to $120 \mathrm{~g} / \mathrm{kg}$. This growth response was consistent with the increase with phytase in digestibility of amino acids recorded in slaughtered pigs rather than the more modest increases in cannulated pigs. The differences in amino acid digestibility responses to phytase by intact and surgically modified animals may be an artefact of the cannulation procedure (Sauer et al. 1989). It may be that modifications of the gut microenvironment by cannulation and/or different feeding regimens have an impact on the response to phytase, perhaps via differences in digesta $\mathrm{pH}$ or the flow of endogenous amino acids. Protein deposition studies may indicate which is the more appropriate method to determine the effect of phytase on protein digestibility in pigs.

\section{Protein utilisation by pigs and poultry}

Several studies have demonstrated improvements in growth performance following phytase supplementation of adequate-P diets, which could be consistent with enhanced protein utilisation. This improvement seems to be particularly the case with weaner pigs (Campbell et al. 1995; Cadogan et al. 1997) and phytase has been shown to improve protein utilisation following supplementation of an amino acid-deficient maize-soyabean weaner diet (Biehl \& Baker, 1996).

An intriguing study with grower pigs (Table 6) was reported by Ketaren et al. (1993), who were able to demonstrate that phytase increased lean tissue deposition. In this study, a basal soyabean meal and sucrose diet, with a total $\mathrm{P}$ content of $2.5 \mathrm{~g} / \mathrm{kg}$, was supplemented with either monosodium phosphate $(244 \mathrm{~g} \mathrm{P} / \mathrm{kg})$ or soyabean meal $(6.7 \mathrm{~g} \mathrm{P} / \mathrm{kg})$ to obtain P levels of 3.25 and $4.0 \mathrm{~g} / \mathrm{kg}$. Overall, phytase addition to the five diets increased protein deposition by $13.9 \%$ (from 108 to $123 \mathrm{~g} / \mathrm{d}$ ) and protein retention by $9.1 \%$ (from 0.33 to $0.36 \mathrm{~kg} / \mathrm{kg}$ ) coupled 
Phytate and phytase and protein utilization

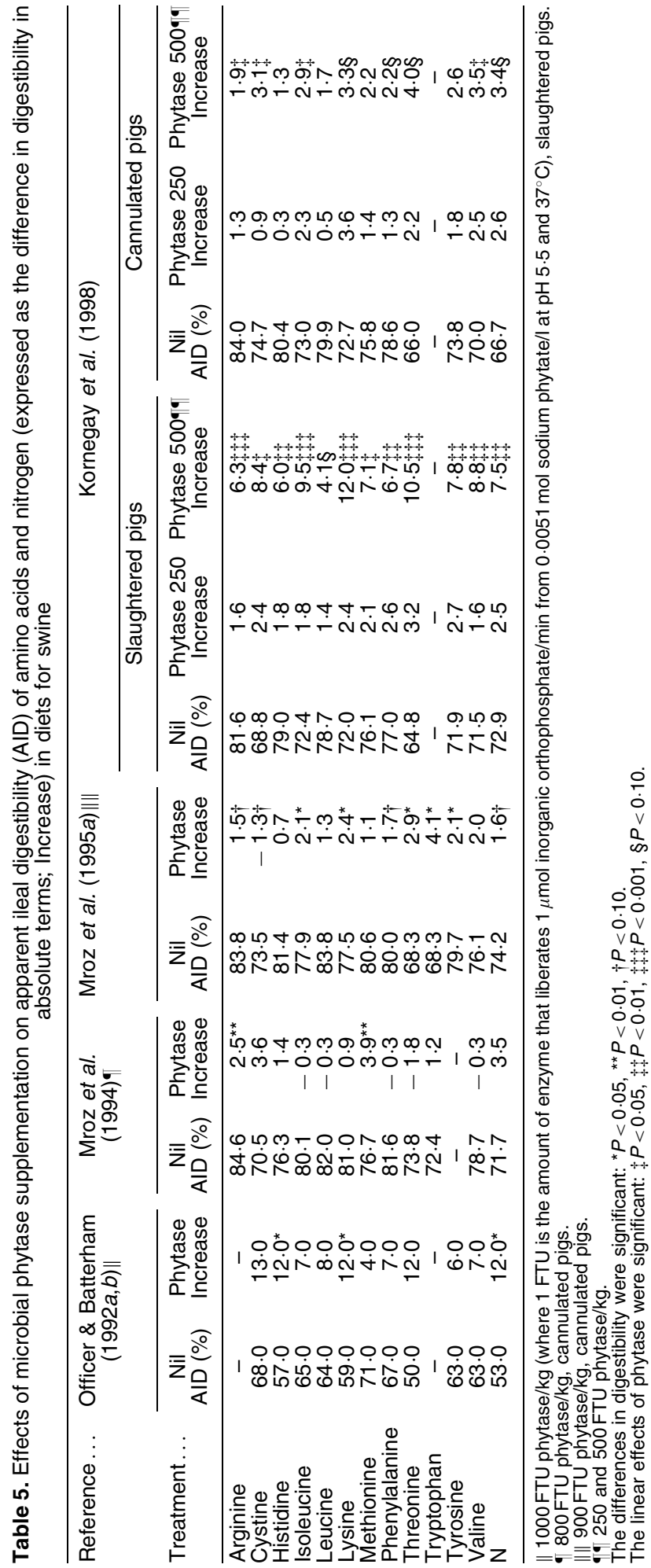


with significant improvements in growth rates $(P<0.05)$ and feed conversion ratios $(P<0.01)$. The possibility that increases in $\mathrm{P}$ availability in these atypical diets contributed to the phytase responses cannot be ruled out. Nevertheless, it would appear that phytase did have a direct positive influence on utilisation of soyabean protein in this study.

In broilers fed on diets based on sorghum and soyabean meal Farrell et al. (1992) showed that the addition of $750 \mathrm{FTU}$ microbial phytase/kg improved $\mathrm{N}$ utilisation. More pronounced increases in $\mathrm{N}$ retention in broilers fed on diets based on sorghum, soyabean meal, rapeseed meal, cottonseed meal and wheat middlings with $600 \mathrm{FTU}$ phytase $/ \mathrm{kg}$ have been reported (Selle et al. 1999). This finding implies that different dietary components or changes in dietary composition modify the response to phytase supplementation.

Using an alternative approach Biehl \& Baker (1997) fed broilers on maize-based diets deficient in amino acids, with soyabean or peanut meals as the protein source. Phytase addition (1200 FTU/kg) improved feed efficiency of the soyabean-meal diet, but had no effect on the corresponding peanut-meal diet. It was concluded that phytase had a positive influence on the utilisation of methionine, threonine, lysine and/or valine from soyabean protein. However, in a subsequent study (Boling et al. 1999) phytase supplementation failed to show improved utilisation of protein in a range of ingredients, as assessed by protein efficiency ratios or sloperatio assays.

In terms of breast-meat weight, phytase supplementation of low-protein maize-soyabean diets enhanced protein utilisation of finisher broiler chickens (Kornegay et al. 1999). In this study, phytase had significant linear effects on breast weight $(P<0 \cdot 01)$ and breast weight as a proportion of carcass weight $(P<0.001)$, presumably by increasing amino acid availability for lean tissue deposition.

The presence of enzymic 'side activities' in microbial phytase preparations, which may impact on the effects of supplementation, is an issue (Farrell \& Martin, 1998). Most phytase feed enzymes are generated by genetically-modified production strain organisms and are

Table 6. Effects of phytase supplementation of a basal diet (BD) and diets supplemented with $P$ as monosodium phosphate (MSP) and soyabean meal (SBM) on performance and protein utilisation of grower pigs (from Ketaren et al. 1993)

\begin{tabular}{|c|c|c|c|c|c|c|}
\hline \multicolumn{3}{|c|}{ Treatment } & \multicolumn{2}{|c|}{ Performance } & \multicolumn{2}{|c|}{ Protein utilisation } \\
\hline Diet & $\begin{array}{l}\text { Phytase } \\
\text { (FTU/kg) }\end{array}$ & $\begin{array}{l}\text { Total P } \\
(\mathrm{g} / \mathrm{kg})\end{array}$ & $\begin{array}{l}\text { Live-wt gain } \\
(\mathrm{g} / \mathrm{d})\end{array}$ & $\begin{array}{l}\text { Feed conversion } \\
\text { ratio }(\mathrm{g} / \mathrm{g})\end{array}$ & $\begin{array}{l}\text { Deposition } \\
\text { (g/d) }\end{array}$ & $\begin{array}{c}\text { Retention } \\
\text { (retained:intake) }\end{array}$ \\
\hline $\begin{array}{l}\text { BD } \\
\text { Response (\%) }\end{array}$ & $\begin{array}{r}0 \\
1000\end{array}$ & 2.50 & $\begin{array}{c}700 \\
841 \\
20 \cdot 1\end{array}$ & $\begin{array}{r}2.64 \\
2.27 \\
14.0\end{array}$ & $\begin{array}{c}100 \\
121 \\
21.0\end{array}$ & $\begin{array}{l}0.325 \\
0.384 \\
18.2\end{array}$ \\
\hline $\begin{array}{l}\mathrm{BD}+\mathrm{MSP} \\
\text { Response (\%) }\end{array}$ & $\begin{array}{r}0 \\
1000\end{array}$ & $3 \cdot 25$ & $\begin{array}{l}833 \\
826 \\
-0.8\end{array}$ & $\begin{array}{l}2.32 \\
2.19 \\
3.9\end{array}$ & $\begin{array}{r}122 \\
125 \\
2.5\end{array}$ & $\begin{array}{l}0.376 \\
0.409 \\
8.8\end{array}$ \\
\hline $\begin{array}{l}\mathrm{BD}+\mathrm{MSP} \\
\text { Response (\%) }\end{array}$ & $\begin{array}{r}0 \\
1000\end{array}$ & 4.00 & $\begin{array}{l}794 \\
915 \\
15 \cdot 2\end{array}$ & $\begin{array}{l}2 \cdot 14 \\
1.96 \\
8 \cdot 4\end{array}$ & $\begin{array}{c}121 \\
134 \\
10 \cdot 7\end{array}$ & $\begin{array}{l}0.428 \\
0.440 \\
2.8\end{array}$ \\
\hline $\begin{array}{l}\text { BD + SBM } \\
\text { Response (\%) }\end{array}$ & $\begin{array}{r}0 \\
1000\end{array}$ & $3 \cdot 25$ & $\begin{array}{l}691 \\
760 \\
10 \cdot 0\end{array}$ & $\begin{array}{l}2.43 \\
2.28 \\
6 \cdot 2\end{array}$ & $\begin{array}{c}97 \\
114 \\
17.5\end{array}$ & $\begin{array}{l}0.264 \\
0.302 \\
14.4\end{array}$ \\
\hline $\begin{array}{l}\text { BD + SBM } \\
\text { Response (\%) }\end{array}$ & $\begin{array}{r}0 \\
1000\end{array}$ & $4 \cdot 00$ & $\begin{array}{l}687 \\
833 \\
21 \cdot 3\end{array}$ & $\begin{array}{l}2.31 \\
2.08 \\
10.0\end{array}$ & $\begin{array}{c}102 \\
120 \\
17 \cdot 6\end{array}$ & $\begin{array}{l}0.249 \\
0.262 \\
5.2\end{array}$ \\
\hline Main effects of phytase & & & $P<0.05$ & $P<0.01$ & $P<0.05$ & $P<0.05$ \\
\hline
\end{tabular}

FTU, phytase activity units, where $1 \mathrm{FTU}$ is the amount of enzyme that liberates $1 \mu$ mol inorganic orthophosphate/min from $0.0051 \mathrm{~mol}$ sodium phytate/l at $\mathrm{pH} 5.5$ and $37^{\circ} \mathrm{C}$. 
reasonably specific for phytase activity. However, one phytase preparation derived from a genetically-modified Tricoderma reesei strain has side xylanase, $\beta$-glucanase and cellulase activities (Zyla et al. 2000). Given sufficient activity, glycanases could enhance the effects of phytase (Ravindran et al. 1999c), and have an independent effect on protein digestibility (Hew et al. 1998). If present, acid phosphatase side activity could be expected to augment phytate hydrolysis (Zyla, 1993).

The phytase feed enzyme used in the majority of amino acid-digestibility studies is derived from a genetically-modified Aspergillus niger. The particular preparation evaluated in a piggrowth study (Campbell et al. 1995) was analysed and contained protease, but not glycanase, side activities (B Grünberg, personal communication). However, the addition of an exogenous protease to a wheat-casein broiler diet did not increase the digestibility of amino acids (Ravindran et al. 1999c). This finding indicates that protease side activity in a phytase feed enzyme would be unlikely to have an independent positive effect on protein digestibility. Presumably any side activities in phytase preparations are relatively minor, but they may increase the hydrolysis of phytate, either by their own phosphorolytic effects or by improving the accessibility of phytase to its substrate. However, the possibility that they have a tangible independent effect on amino acid digestibility appears remote. It is deduced that increases in the digestibility of amino acids following phytase supplementation are consequential to phytate hydrolysis, which may be facilitated by side activities in the preparation.

\section{Mechanisms contributing to the negative effects of phytate on protein utilisation}

Protein-phytate complexes may be present in plant feedstuffs, but the majority of such complexes are probably formed de novo in the gastrointestinal tract (see p. 268). Irrespective of the origin of these complexes, the inference of the data reviewed earlier is that phytate has a negative influence on protein availability, which could occur in a number of ways, but this antinutritive property is ameliorated by phytase. In addition, by interacting with digestive enzymes or their substrates, phytate may reduce the effectiveness of these enzymes, which could lead to decreased digestion of dietary protein and increased endogenous amino acid losses.

\section{Protein-phytate complexes inherent in feedstuffs}

The extent to which protein-phytate complexes are inherently present in seeds is unclear, although a physical association between protein and phytate in the protein bodies of dicotyledonous seeds and in the protein-rich aleurone layers of monocotyledonous seeds is recognised (Ravindran et al. 1995). Early reports suggested protein-phytate complexes were present in beans (Bourdillon, 1951) and soyabeans (Prattley \& Stanley, 1982), but these complexes may have been artefacts, formed as a result of the extraction procedure. De Boland et al. (1975) found that phytate from soyabean flakes was soluble, whereas phytate from isolated soyabean protein was completely insoluble; this observation suggests that insoluble protein-phytate complexes, that were not present in native soyabean seeds, were formed during the preparation of the soyabean-protein isolates. It is possible that processing of feed ingredients (e.g. heat treatment, oil extraction) may permit phytate interactions with protein. While proteinmineral-phytate complexes may be present in native seeds, it seems possible that the bonds could be disrupted by the acidic conditions of the upper gastrointestinal tract. 


\section{De novo formation of binary protein-phytate complexes}

Binary protein - phytate complexes are formed below the isoelectric point of proteins $(\mathrm{pH}<5-$ 6). Phytate interacts with terminal $\alpha-\mathrm{NH}_{2}$ groups and side-groups of basic amino acids, which include arginine (isoelectric point $\mathrm{pH}$ 10.8), histidine (isoelectric point $\mathrm{pH} 7 \cdot 6$ ) and lysine (isoelectric point $\mathrm{pH}$ 9.7). Strong electrostatic attractions between negatively charged phytates and proteins with a net positive charge, result in the formation of protein-phytate complexes (Cosgrove, 1966). The interaction of phytate and protein at acid $\mathrm{pH}$ has been demonstrated in a number of in vitro studies. Barré \& Nguyen-Van-Huot (1965) found that phytate interacted with human serum albumin; sequentially binding with the terminal $\alpha-\mathrm{NH}_{2}$ groups, the $\varepsilon-\mathrm{NH}_{2}$ group of lysine, histidine residues and the guanido groups of arginine. Similarly, phytate interacts very strongly with human deoxyhaemoglobin affecting its $\mathrm{O}_{2}$-binding capacity. Crystal structure studies have shown that the interaction is through two histidine groups, a lysine group and the terminal amino group (Arnone \& Perutz, 1974).

Okubo et al. (1976) reported binary complex formation between sodium phytate and glycinin, the major globulin protein in soyabeans. Binding was not detected above the isoelectric point of glycinin ( $\mathrm{pH} 4.9$ ); however, as the $\mathrm{pH}$ was reduced to 2.5 protein-phytate complexes precipitated. The interaction was consistent with the number of binding sites provided by lysine, histidine and arginine. Rajendran \& Prakash (1993) investigated the kinetics and thermodynamics of the protein-phytate interaction between sodium phytate and $\alpha$-globulin derived from sesame seed. The maximum interaction occurred at $\mathrm{pH} 2.3$ and was dependent on the phytate:protein value. In the initial rapid step phytate bound with protein leading to conformational changes. Subsequently, there was a progressive protein-protein aggregation, leading to precipitation.

It has been proposed that phytate may bind with crystalline amino acids in the gut (ACE Edwards, personal communication). In an in vitro study lysine monohydrochloride was incubated with rice polishings, as a source of phytate, with and without phytase at $\mathrm{pH} 4.5$ (Rutherfurd et al. 1997). Incubation without phytase reduced the recovery of free lysine by $22 \%$, but with the addition of phytase the loss was $9 \%$, suggesting phytate did interact with free lysine. This possibility was confirmed in a second experiment where similar recovery patterns were observed for lysine when practical grower and finisher diets for pigs were incubated with and without phytase at pH 2.5 (Rutherfurd \& Moughan, 1997). The implication is that phytate may reduce the in vivo utilisation of supplementary lysine.

Camus \& Laporte (1976) suggested that protein complexed with phytate is refractory to pepsin activity. These workers found that sodium phytate and aqueous extracts from wheat reduced the in vitro proteolysis of casein and gluten by pepsin at $\mathrm{pH} 2 \cdot 0$. This reduction in enzyme activity was attributed to the formation of insoluble pepsin-resistant complexes between phytate and protein in the acid medium. Subsequent findings (Kanaya et al. 1976; Inagawa et al. 1987; Knuckles et al. 1989; Vaintraub \& Bulmaga, 1991) support this hypothesis, since phytate consistently reduced the in vitro pepsin digestion of both plant and animal proteins. Apparently, this reduction is dependent on phytate complexing with the substrate protein, rendering the target resistant to pepsin proteolysis, presumably due to reduced solubility and structural changes associated with aggregation (Vaintraub \& Bulmaga, 1991).

Jongbloed et al. (1997) considered that insoluble protein-phytate complexes are likely to be formed in the stomach of pigs at protein:phytate values encountered in normal diets. It has been suggested that phytate is mainly bound to proteins rather than minerals at acidic $\mathrm{pH}$ (Wise, 1983). It seems likely that phytate can complex a substantial proportion of dietary protein in the upper gastrointestinal tract. It is relevant that supplemental microbial phytase is most active in 
the acid medium of the stomach of pigs (Jongbloed et al. 1992; Yi \& Kornegay, 1996). If binary protein-phytate complexes are mainly formed de novo in the gut, it is plausible that phytase would more readily hydrolyse soluble phytates to relatively innocuous lower inositol phosphate esters (Lonnerdal et al. 1989) than insoluble protein-phytate complexes where the substrate is 'protected' by protein (Konishi et al. 1999). It is likely therefore, that phytase may primarily prevent the formation of binary protein-phytate complexes by the previous hydrolysis of phytate rather than releasing bound amino acids from existing complexes.

It would appear that the initiation of protein digestion by pepsin in the stomach is impeded by phytate forming refractory binary complexes. However, at intermediate $\mathrm{pH}$ levels $(>5-6)$, above the isoelectric point of protein, the positive charge of the protein is neutralised and the binary complex dissociates, so the complexes are ephemeral. In terms of the digestibility of dietary amino acids, phytate may increase the molecular size and alter the structure of proteins flowing into the small intestine as a result of primary complex formation. By reducing the formation or disrupting these complexes in the stomach, phytase may have a positive effect on the subsequent rate of digestion and absorption of amino acids in the small intestine. The possibility of refractory substrates causing increased pepsin secretion was considered, as large variations in pepsin activity in the proximal duodenum in response to different diets have been reported in grower pigs (Zebrowska et al. 1983). However, there does not appear to be a mechanism to promote such a response. Peptides arising from pepsin proteolysis trigger the release of hormones, including gastrin and cholecystokinin, which regulate the digestion and absorption of protein (Hersey, 1987). Possibly the interference of pepsin digestion by phytate has a negative effect on secondary function of pepsin as an overall regulator of the protein digestive process.

\section{De novo formation of ternary phytate-protein complexes}

Ternary protein-phytate complexes may be formed in the small intestine; these proteinmineral-phytate complexes are formed only in the presence of divalent cations, particularly $\mathrm{Ca}^{2+}$. It appears that the unprotonated imidazole group of histidine and/or the ionised carboxyl groups of protein are linked to phytate via a cationic bridge. The formation of ternary proteinphytate complexes at intestinal $\mathrm{pH}$ values has been supported by data from a number of experiments using ultrafiltration (Okubo et al. 1975; de Rahm \& Jost, 1979; Omosaiye \& Cheryan, 1979; Prattley et al. 1982) and dialysis (Smith \& Rackis, 1957; Honig et al. 1984) techniques, as outlined by Champagne et al. (1990). Interactions between phytate, modified histidine ( $\alpha$-N-acetyl-L-histidine) and $\mathrm{Ca}, \mathrm{Zn}$ and $\mathrm{Cu}$ at $\mathrm{pH} 7$ have been examined (Champagne et al. 1990). Spectroscopic examination, involving NMR and electron spin resonance, indicated the existence of soluble ternary complexes involving phytate, histidine and the three cations. Nosworthy \& Caldwell (1988) also found that at $\mathrm{pH} 6 \cdot 2$ phytate interacted with glycinin, in the presence of $\mathrm{Zn}$, presumably resulting in ternary complex formation.

The relative importance of ternary protein-phytate complexes is difficult to assess, as phytate could form either mineral-phytate complexes or ternary protein-phytate complexes in the small intestine. In fact, an equilibrium may exist as illustrated by the following equation (adapted from Champagne, 1988):

protein $+\mathrm{Ca}+$ phytate $\leftrightarrows[$ protein $-\mathrm{Ca}-$ phytate $] \leftrightarrows[\mathrm{Ca}-$ phytate $]+$ protein

It was suggested that $\mathrm{Ca}$ concentrations would affect the extent of ternary protein-phytate complex formation. Excess $\mathrm{Ca}$ would lead to the formation of $\mathrm{Ca}$-phytate complexes, which are highly insoluble and poorly digested (Gifford \& Clydesdale, 1990). While ternary com- 
plexes are thought to reduce protein digestibility, tangible evidence is lacking. As the protein component may consist of amino acids or small peptides (Champagne et al. 1990), relatively little protein may be bound by phytate in these complexes, but the rates and site of absorption of amino acids may be altered. Supplemental phytase would be expected to reduce the amount of phytate in the digesta flowing into the small intestine, thus largely preventing the formation of ternary complexes.

\section{Phytate interactions with digestive enzymes}

The possibility that phytate may inhibit proteolysis by altering the protein configuration of digestive enzymes was suggested by Singh \& Krikorian (1982). These workers reported that sodium phytate reduced the in vitro digestion of casein by up to $46 \%$ when trypsin was preincubated with phytate. It was postulated that phytate may bind with trypsin via Ca forming a ternary complex, thus inhibiting trypsin activity. However, several subsequent investigations (Kanaya et al. 1976; Inagawa et al. 1987; Reddy et al. 1988; Knuckles et al. 1989; Vaintraub \& Bulmaga, 1991) have failed to demonstrate phytate inhibition of trypsin. Desphande \& Damodaran (1989) did find that phytate slightly reduced the solubility of trypsin in the presence of $\mathrm{Ca}$ at $\mathrm{pH} 7 \cdot 8$, and spectroscopic studies showed that phytate caused conformational changes to trypsin. However, phytate did not have adverse effects on the in vitro digestion of casein by trypsin.

Caldwell (1992) investigated the in vitro effects of sodium phytate and $\mathrm{CaCl}_{2}$ on the activation of trypsinogen and the stability of trypsin. Phytate addition to a reaction mixture containing $\mathrm{Ca}$ reduced the activation of trypsinogen by approximately $90 \%$ at $\mathrm{pH} 8 \cdot 1$, and further incubation reduced the active trypsin content. It was concluded that $\mathrm{Ca}$-phytate complexes increased the formation of inactive trypsin and substantially reduced the stabilising effect of $\mathrm{Ca}$ on trypsin integrity. Although the pancreas has the capacity to compensate for low trypsin levels by increasing trypsinogen output in response to negative feedback mechanisms, the author considered the effects of phytate on trypsin could still have adverse effects.

While conclusions from in vitro data are divided, only one relevant in vivo study (Mroz et al. 1995b) has been identified. In sows phytase was found to increase both ileal digestibility of $\mathrm{N}(3.7 \%)$ and trypsin activity $(10.9 \%)$ to a significant $(P<0.05)$ extent. These increases are not necessarily related, but the possibility that phytate may inhibit the activity of trypsin, and other digestive enzymes, is a critical unresolved issue.

\section{Phytate and endogenous amino acid losses}

It has been proposed that phytate may increase endogenous protein losses (Ravindran et al. 1999a). The relatively pronounced effect of microbial phytase on the digestibility of threonine in the majority of studies lends support to this premise, since endogenous secretions are known to contain relatively high concentrations of threonine in pigs (Taverner et al. 1981) and poultry (Siriwan et al. 1994). Although specific studies relating to phytic acid are lacking, evidence with other anti-nutritive factors (such as trypsin inhibitors, NSP) indicate that these components can significantly increase endogenous $\mathrm{N}$ flows in pigs (Caine et al. 1998) and poultry (Angkanaporn et al. 1994).

Trypsin inhibition has been shown to increase endogenous protein losses in pigs (Barth et al. 1993). In this study inhibition of trypsin had a more pronounced effect on endogenous losses than on the digestibility of dietary amino acids. Several in vitro investigations (Sharma et al. 
1978; Desphande \& Cheryan, 1984; Thompson \& Yoon, 1984) have found phytate to be a potent non-competitive inhibitor of $\alpha$-amylase activity. It follows that in vivo inhibition of digestive enzymes by phytate may promote endogenous losses and reduce the apparent ileal digestibility of amino acids.

\section{Phytate and energy responses to phytase}

It is being increasingly documented that supplemental phytase can enhance the apparent metabolisable energy of poultry diets based on wheat (Ravindran et al. 2000b), sorghum (Farrell et al. 1992; Selle et al. 1999), a wheat-sorghum blend (Ravindran et al. 2000a), maize (Ledoux et al. 1999; Namkung \& Leeson, 1999), and oats (Farrell \& Martin, 1993). If phytase has positive independent effects on energy utilisation, it follows that this factor would enhance protein utilisation, and therefore assumes relevance. It is not clear whether similar energy effects occur with phytase supplementation of diets for pigs.

The increased energy utilisation following phytase supplementation of poultry is partially a reflection of increased protein digestibility. However, phytase may also have independent energy effects. Phytate reduces glucose absorption rates, which led to the suggestion that phytate may adversely affect starch digestion by interacting with starch directly, or proteins closely associated with starch granules, with inhibition of amylase activity a third possibility (Thompson \& Yoon, 1984; Thompson, 1988). In addition, it has been postulated (Ravindran et al. 2000a) that Caphytate may increase the formation of metallic soaps in the gut lumen, with a corresponding reduction in the utilisation of saturated fats. These assumptions, if valid, may provide mechanisms for the enhancement of energy utilisation by phytase, independent of its protein effect. In the case of wheat an additional mode of action may be involved in the improvement of apparent metabolizable energy. Ravindran et al. (1999a) reported that microbial phytase appears to act on wheat in a manner similar to that of exogenous glycanases, perhaps by disrupting the cell walls and enhancing the contact between digestive enzymes and cell contents. This possibility is to be anticipated, since phytate is an integral component of cell walls in wheat.

\section{Factors responsible for variable protein responses to added phytase}

As the present review demonstrates, there is considerable variation in the reported amino acid responses to phytase supplementation. Factors influencing the magnitude of responses are complex, and probably include the source and concentration of phytate and protein in the diet, the digestibility of the protein component, $\mathrm{Ca}$ and $\mathrm{P}$ levels and the phytase inclusion rate. In addition, the method of collection of ileal digesta samples to determine amino acid digestibility from pigs is apparently another source of variation. These aspects have not been extensively investigated.

One consistent overall finding is that poorly-digestible feedstuffs are more responsive to phytase addition than those with higher inherent digestibility (Table 4). This factor is illustrated by the negative correlation $(P<0 \cdot 01)$ between inherent amino acid digestibility and phytase responses (Table 7). Amino acid digestibilities were influenced by dietary phytate concentrations, as $66 \%$ of the variation in digestibility was explained by the level of phytate in the nine ingredients evaluated. These data imply that phytate in feed ingredients is a major factor determining amino acid digestibility. In this study (Ravindran et al. 1999a), however, it was anticipated that responses to phytase would be greater in ingredients containing high levels of phytate. While the magnitude of response to phytase varied among ingredients, there was no significant correlation between the percentage improvements in average amino acid digest- 
ibility and phytate concentrations (Table 7). Thus, it would appear that the responses to supplemental phytase may be influenced by more subtle structural or chemical properties of both phytate and protein rather than by the total concentrations of phytate. The source of phytate and protein appears to contribute to the variability.

The propensity for proteins from different feedstuffs to be bound by phytate varies (Champagne, 1988), so the capacity of phytate to complex with proteins may be a key variable. The relevant properties may include the structure, the accessibility of relevant amino acid residues and solubility of the protein at different $\mathrm{pH}$ values. For example, maize is less responsive to phytase than wheat (Ravindran et al. 1999a). This finding is consistent with the lack of evidence of interactions between protein and phytate of maize germ (O'Dell \& de Boland, 1976), whereas the formation of protein-phytate complexes in wheat has been reported (Hill \& Tyler, 1954).

In practice, the addition rate of phytase in diets for pigs and broiler chicks is usually 500 or $600 \mathrm{FTU} / \mathrm{kg}$; however, in the studies reviewed the inclusion rates ranged from 125 to $1200 \mathrm{FTU} / \mathrm{kg}$. This obvious source of variation would be compounded by any factors that influence the efficacy of phytase. Dietary levels of both $\mathrm{Ca}$ and $\mathrm{P}$ may influence the hydrolysis of phytate (Ballam et al. 1984). This factor is probably illustrated by the adverse effects of dicalcium phosphate on the amino acid digestibility responses to phytase in broiler chicks (Ravindran et al. 2000a). It may be that high dietary $\mathrm{P}$ levels reduce phytase activity via negative feedback mechanisms. Dietary levels of $\mathrm{P}$ have been shown to alter the response to microbial phytase in turkey poults (Yi et al. 1996). It is widely held that high levels of inorganic $\mathrm{Ca}$ (or wide $\mathrm{Ca}: \mathrm{P}$ values) have a negative influence on the efficacy of phytase. It has been proposed that the poor solubility of Ca-phytate (Wise, 1983) and other mineral - phytate complexes (Maenz et al. 1999) renders phytate resistant to phytase activity. These mineral-phytate complexes are usually formed at a $\mathrm{pH}$ that is above, or at the upper end of the activity spectrum of microbial phytase. Thus, the prevailing $\mathrm{pH}$ in the gut may have an important influence on the efficacy of phytase. The bi-phasic $\mathrm{pH}$ profile of microbial phytase activity (Simons et al. 1990) indicates that subtle changes in $\mathrm{pH}$ of the upper digestive tract could influence the activity of the feed enzyme.

Phytate from cottonseed is more resistant to phytase activity than that from soyabean meal when measured in vitro (Han, 1988), so the susceptibility of phytate from different feed ingredients to phytase activity probably varies. This variation may be a partial reflection of solubility at acidic $\mathrm{pH}$ as, presumably, soluble phytates will be more readily hydrolysed by phytase. The solubilities of protein and phytate over a range of $\mathrm{pH}$ values have been established in vitro for some feed ingredients, including rice bran (Champagne et al. 1985), soyabean, peanut, cottonseed (Fontaine et al. 1946) and rapeseed meals (Gillberg \& Tornell, 1976). These protein and phytate solubility profiles may provide an indication of the contribution of different feed ingredients to proteinphytate complex formation and phytate degradation by phytase in the gut.

Table 7. Correlation between dietary phytic acid and inherent protein or amino acid (AA) digestibility and phytase responses in protein digestibility and mean amino acid digestibility, based on the data from Ravindran et al. (1999a) in Table 4

\begin{tabular}{lc}
\hline Correlation & $r$ \\
\hline Dietary phytic acid $v$. inherent protein digestibility & $-0 \cdot 81^{\star \star \star}$ \\
Dietary phytic acid $v$. phytase responses in protein digestibility & -0.20 \\
Dietary phytic acid $v$. phytase responses in mean AA digestibility & 0.12 \\
Inherent protein digestibility $v$. phytase responses in protein digestibility & $-0.42^{\star}$ \\
Inherent mean AA digestibility $v$. phytase responses in mean AA digestibility & $-0.51^{\star \star}$
\end{tabular}

${ }^{*} P<0.05$.

** $P<0.01$

${ }^{* \star *} P<0.001$. 


\section{Concluding comments}

The nutritional consequences of protein-phytate interactions in reducing the utilisation of dietary protein are important. The extent of binary protein-phytate complex formation in the upper digestive tract may be a crucial factor in determining the anti-nutritive properties of phytate in relation to protein. In a complete diet this factor may be largely dependent on the structure of the proteins and the relative concentrations of soluble phytates and proteins. These characteristics, in turn, coupled with the susceptibility and/or accessibility of phytate and the $\mathrm{pH}$ of the gut, may define the possible benefits of dietary supplementation with microbial phytase. In addition, by interacting with digestive enzymes phytate may cause an increase in the secretion of digestive enzymes into the gut, thus increasing the endogenous loss of amino acids. Phytase is capable of increasing the utilisation of dietary amino acids and $\mathrm{N}$ by countering these anti-nutritive properties of phytate.

Provided that appropriate dietary formulations are employed, the pig and poultry industries should be well placed to benefit from the 'protein effect' of phytase feed enzymes in practice. However, it must be recognised that the amino acid responses to phytase addition are variable, and obviously more attention should be paid to the factors responsible for these variations. The effects of phytate and phytase on the in vivo activity of digestive enzymes, particularly trypsin, and their effects on endogenous amino acid flows merit investigation. Protein-deposition studies, particularly in pigs, appear justified. Such studies should provide a more fundamental assessment of the effects of phytate and phytase on protein utilisation, and may help resolve the discrepancies in amino acid digestibility responses to phytase with methods of ileal digesta collection. Additional studies should be completed in pigs and poultry to determine the effects of phytase on the amino acid digestibility of individual feed ingredients. The probability is that vegetable protein and cereal sources differ in their amino acid digestibility responses to phytase supplementation, which may stem from the propensity of protein to be complexed by phytate and the susceptibility of the substrate to hydrolysis by phytase. These differences have considerable implications for feed compounders, and delineation of these differences will facilitate the derivation of amino acid replacement values for microbial phytase in least-cost diet formulations, and further reduce $\mathrm{N}$ excretion and pollution.

\section{Acknowledgements}

The authors gratefully acknowledge the continued cooperation of $\mathrm{Mr}$ A. R. Walker of BRI Australia Ltd, North Ryde, NSW, Australia in generating data shown in Table 1.

\section{References}

Anderson PA (1985) Interactions between proteins and constituents that affect protein quality. In Digestibility and Amino Acid Availability in Cereals and Oilseeds, pp. 31-45 [JW Finley and DT Hopkins, editors]. St Paul, MN: American Association of Cereal Chemists, Inc.

Angkanaporn K, Choct M, Bryden WL \& Annison EF (1994) Effects of wheat pentosans on endogenous amino acid losses in chickens. Journal of the Science of Food and Agriculture 66, 399-404.

Arnone A \& Perutz MF (1974) Structure of inositol hexaphosphate-human deoxyhaemoglobin complex. Nature 249, 34-36.

Ballam GC, Nelson TS \& Kirby LB (1984) Effect of fiber and phytate source and of calcium and phosphorus level on phytate hydrolysis in the chick. Poultry Science 63, 333-338.

Barnett BJ, Clarke WA \& Batterham ES (1993) Has phytase a proteolytic effect in diets for weaner pigs? In Manipulating Pig Production, vol. 4, p. 227 [ES Batterham, editor]. Werribee, Victoria: Australasian Pig Science Association. 
Barré R \& Nguyen-van-Huot N (1965) Etudé de la combination de l'acide phytique avec la serum-albumine humaine native, acetylee et des amine (Study of the combination of phytic acid and native human serum albumin, acetylate and amines). Bulletin de Société de Chimie Biologique 47, 1399-1417.

Barrier-Guillot B, Casado P, Maupetit P, Jondreville C \& Gatel F (1996) Wheat phosphorus availability: 1-In vitro study: factors affecting endogenous phytasic activity and phytic phosphorous content. Journal of the Science of Food and Agriculture 70, 62-68.

Barth CA, Lunding B, Schmitz M \& Hagemeister H (1993) Soybean trypsin inhibitor(s) reduce absorption of exogenous and increase loss of endogenous protein in miniature pigs. Journal of Nutrition 123, 2195-2200.

Beers S \& Jongbloed AW (1992) Effect of supplementary Aspergillus niger phytase in diets for piglets on their performance and apparent digestibility of phosphorus. Animal Production 55, 425-430.

Biehl RR \& Baker DH (1996) Efficacy of supplemental $1 \alpha$-hydroxycholecalciferol and microbial phytase for young pigs fed phosphorus- or amino acid-deficient corn-soyabean meal diets. Journal of Animal Science 74, $2960-2966$.

Biehl RR \& Baker DH (1997) Microbial phytase improves amino acid utilization in young chicks fed diets based on soyabean meal but not diets based on peanut meal. Poultry Science 76, 355-360.

Boling SD, Peter CM, Douglas MW, Strunk CS, Parsons CM \& Baker DH (1999) Efficacy of phytase for increasing protein efficiency ratio (PER) values of feed ingredients. Poultry Science 78, Suppl. 1, 75 Abstr.

Bourdillon J (1951) Crystalline bean seed protein in combination with phytic acid. Journal of Biological Chemistry 189, 65-72.

Cabahug S, Ravindran V, Bryden WL \& Selle PH (1999) Response of broilers to microbial phytase supplementation as influenced by dietary phytic acid and non-phytate phosphorus levels. I. Effects on broiler performance and toe ash content. British Poultry Science 40, 660-666.

Cadogan DJ, Selle PH, Campbell RG \& Walker AR (1997) Effects of dietary phytate phosphorus and microbial phytase on the performance of weaner pigs. In Manipulating Pig Production, vol. 6, p. 245 [PD Cranwell, editor]. Werribee, Victoria: Australasian Pig Science Association.

Caine WR, Sauer WC, Verstegen WA, Tamminga S, Li S \& Schulze H (1998) Guanidated protein test meals with higher concentration of soyabean trypsin inhibitors increase ileal recoveries of endogenous amino acids in pigs. Journal of Nutrition 128, 598-605.

Caldwell RA (1992) Effect of calcium and phytic acid on the activation of trypsinogen and the stability of trypsin. Journal of Agricultural and Food Chemistry 40, 43-46.

Campbell GL \& Bedford MR (1992) Enzyme applications for monogastric feeds: A review. Canadian Journal of Animal Science 72, 449-466.

Campbell RG, Harrison DT, Butler KJ \& Selle PH (1995) Effects of dietary available phosphorus and phytase (Natuphos) on the performance of pigs from 19 to 40 days post-weaning. In Manipulating Pig Production, vol. 5, p. 193 [DP Hennessy and PD Cranwell, editors]. Werribee, Victoria: Australasian Pig Science Association.

Camus MC \& Laporte JC (1976) Inhibition de la protéolyse pesique par le blé. Rôle de l'acide phytique des issues. (Inhibition of pepsin proteolysis by wheat. Role of phytic acid in the outcome). Annales de Biologie Animale Biochimie Biophysique 16, 719-729.

Champagne ET (1988) Effects of $\mathrm{pH}$ on mineral-phytate, protein-mineral-phytate and mineral-fiber interactions. Possible consequences of atrophic gastritis on mineral bioavailability from high fiber foods. Journal of the American College of Nutrition 7, 499-508.

Champagne ET, Fisher MS \& Hinojosa O (1990) NMR and ESR studies of interactions among divalent cations, phytic acid, and N-acetyl-amino acids. Journal of Inorganic Biochemistry 38, 199-215.

Champagne ET, Rao RM, Liuzzo JA, Robinson JW, Gale RJ \& Miller F (1985) Solubility behaviours of the minerals, proteins and phytic acid in rice bran with time temperature and $\mathrm{pH}$. Cereal Chemistry 62, 218-222.

Cheryan M (1980) Phytic acid interactions in food systems. CRC Critical Reviews in Food Science and Nutrition 13, 297-335.

Cosgrove DJ (1966) The chemistry and biochemistry of inositol polyphosphates. Reviews of Pure and Applied Chemistry 16, 209-224.

Cosgrove DJ (1980) Inositol Phosphates. Their Chemistry, Biochemistry and Physiology. Amsterdam, The Netherlands: Elsevier Scientific Publishing.

de Boland AR, Garner GB \& O'Dell BL (1975) Identification and properties of 'phytate' in cereal grains and oilseed products. Journal of Agricultural and Food Chemistry 23, 1186-1189.

de Rham O \& Jost T (1979) Phytate-protein interactions in soyabean extracts and low-phytate soy protein products. Journal of Food Science 44, 596-600.

Desphande SS \& Cheryan M (1984) Effects of phytic acid divalent cations and their interactions on $\alpha$-amylase activity. Journal of Food Science 49, 516-519.

Desphande SS \& Damadaran S (1989) Effect of phytate on solubility, activity and conformation of trypsin and chymotrypsin. Journal of Food Science 54, 695-699.

Eeckhout W \& de Paepe M (1991) The quantitative effects of an industrial microbial phytase and wheat phytase on the apparent phosphorus absorbability of a mixed feed by piglets. Medical Faculty Landbouw Rijkuniversity, Gent 56, 1643-1647.

Engelen AJ, van der Heeft FC, Randsdorp PHG \& Smit ELC (1994) Simple and rapid determination of phytase activity. Journal of the Association of Official Analytical Chemists International 77, 760-764. 
Fandrejewski H, Raj S, Weremko D \& Zebrowska T (1997) Apparent digestibility in experimental feeds and the effect of commercial phytase. Asian-Australasian Journal of Animal Science 10, 665-670.

Farrell DJ \& Martin E (1993) Feed enzymes in poultry nutrition: recent findings. Recent Advances in Animal Nutrition in Australia, pp. 266-276 [DJ Farrell, editor]. Armidale, NSW: University of New England.

Farrell DJ \& Martin E (1998) Strategies to improve the nutritive value of rice bran in poultry diets. III. The addition of inorganic phosphorus and a phytase to duck diets. British Poultry Science 39, 601-611.

Farrell DJ, Martin E, Du Preez JJ, Bongarts M, Betts M, Sudaman A \& Thomson E (1992) The improvement in phosphorus availability when phytase is added to broiler diets. Proceedings of the Australian Poultry Science Symposium, vol. 4, pp. 116-119 [RJ Johnson, editor]. Sydney, NSW: Poultry Research Foundation and the World's Poultry Science Association.

Fontaine TD, Pons WA \& Irving GW (1946) Protein-phytate relationship in peanuts and cottonseed. Journal of Biological Chemistry 164, 487-507.

Frolich W \& Asp N-G (1985) Minerals and phytate in the analysis of dietary fiber from cereals. III. Cereal Chemistry 62, 238-242.

Gifford SR \& Clydesdale FM (1990) Interactions among calcium, zinc and phytate with three protein sources. Journal of Food Science 55, 1720-1724.

Gillberg L \& Tornell B (1976) Preparation of rapeseed protein isolates. Dissolution and precipitation behaviour of rapeseed proteins. Journal of Food Science 41, 1063-1069.

Graf E (1986) Phytic acid: Chemistry and Applications. Minneapolis, MN: Pilatus Press.

Graf E \& Eaton JW (1993) Suppression of colonic cancer by dietary phytic acid. Nutrition and Cancer 19, 11-19.

Greiner R, Konietzny U \& Jany Kl-D (1993) Purification and characterization of two phytases from Escherichia coli. Archives of Biochemistry and Biophysics 303, 107-113.

Han YW (1988) Removal of phytic acid from soyabean and cottonseed meals. Journal of Agricultural and Food Chemistry 36, 1181-1183.

Harland BF \& Morris ER (1995) Phytate: a good or bad food component? Nutrition Research 15, $733-754$.

Hersey SJ (1987) Pepsin secretion. In Physiology of the Gastrointestinal Tract, vol. 2, pp. 947-957 [LR Johnson, editor]. New York: Raven Press.

Hew LI, Ravindran V, Mollah Y \& Bryden WL (1998) Influence of exogenous xylanase supplementation on apparent metabolisable energy and amino acid digestibility in wheat for broiler chickens. Animal Feed Science and Technology 75, 83-92.

Hill R \& Tyler C (1954) The reaction between protein and phytate. Journal of Agricultural Science 44, $324-326$.

Honig DH, Wolf WJ \& Rackis JJ (1984) Phytic acid and phosphorus content of various soyabean protein fractions. Cereal Chemistry 61, 523-526.

Hu HL, Wise A \& Henderson C (1996) Hydrolysis of phytate and inositol tri-, tetra-, and penta-phosphates by the intestinal mucosa of the pig. Nutrition Research 16, 781-787.

Inagawa J, Kiyosawa I \& Nagasawa T (1987) Effects of phytic acid on the digestion of casein and soyabean protein with trypsin, pancreatin and pepsin. Nippon Eiyo Shokuryo Gakkaishi 40, 367-373.

Jones DB \& Csonka FA (1925) Proteins of the cottonseed. Journal of Biological Chemistry 64, 673-683.

Jongbloed AW, de Jonge L, Kemme PA, Mroz Z \& Keis AK (1997) Non-mineral related effects of phytase in pig diets. 6th Forum on Animal Nutrition, pp. 92-106. Ludwigshafen: BASF.

Jongbloed AW \& Kemme PA (1990) Effect of pelleting mixed feeds on phytase activity and the apparent absorbability of phosphorus and calcium in pigs. Animal Feed Science and Technology 28, 233-242.

Jongbloed AW, Mroz Z \& Kemme PA (1992) The effect of supplementary Aspergillus niger phytase in diets for pigs on concentration and apparent digestibility of dry matter, total phosphorus, and phytic acid in different sections of the alimentary tract. Journal of Animal Science 70, 1159-1168.

Kanaya K, Yasumoto K \& Mitsuda H (1976) Pepsin inhibition by phytate contained in rice bran. Eiyo To Shokuryo 29, $341-346$.

Ketaren PP, Batterham ES, Dettmann EB \& Farrell DJ (1993) Phosphorus studies in pigs. 3. Effect of phytase supplementation on the digestibility and availability of phosphorus in soya-bean meal for grower pigs. British Journal of Nutrition 70, 289-311.

Knuckles BE, Kuzmicky DD, Gumbmann MR \& Betschart AA (1989) Effect of myo-inositol phosphate esters on in vitro and in vivo digestion of protein. Journal of Food Science 54, 1348-1350.

Konishi C, Matsui T, Park H, Yano H \& Yano F (1999) Heat treatment of soyabean and rapeseed meals suppress rumen degradation of phytate phosphorus in sheep. Animal Feed Science and Technology 80, 115-122.

Kornegay ET (1996a) Nutritional, environmental and economic considerations for using phytase in pig and poultry diets. In Nutrient Management of Food Animals to Enhance and Protect the Environment, pp. 277-302 [ET Kornegay, editor]. Boca Raton, FL: CRC Press.

Kornegay ET (1996b) Effect of Natuphos ${ }^{\complement}$ phytase on protein and amino acid digestibility and nitrogen retention of poultry. In Phytase in Animal Nutrition and Waste Management, pp. 493-514 [MB Coelho and ET Kornegay, editors]. Mount Olive, NJ: BASF Corporation.

Kornegay ET, Denbow DM \& Zhang Z (1999) Influence of microbial phytase supplementation of a low protein/amino acid diet on performance, ileal digestibility of protein and amino acids, and carcass measurements of finishing broilers. In Phytase in Animal Nutrition and Waste Management, pp. 557-572 [MB Coelho and ET Kornegay, editors]. Mount Olive, NJ: BASF Corporation. 
Kornegay ET, Radcliffe JS \& Zhang Z (1998) Influence of phytase and diet composition on phosphorus and amino acid digestibilities, and phosphorus and nitrogen excretion in swine. BASF Technical Symposium Preceding Carolina Swine Nutrition Conference, pp. 125-155. Mount Olive, NJ: BASF Corporation.

Ledoux DR, Firman JD, Broomhead JN \& Li YC (1999) Effects of microbial phytase on apparent ileal digestibility of amino acids in turkey poults fed a corn-soyabean meal diet formulated on an ideal protein basis. Poultry Science 78, Suppl. 1, 74 Abstr.

Lenis NP \& Jongbloed AW (1999) New technologies in low pollution swine diets: diet manipulation and use of synthetic amino acids, phytase and phase feeding for reduction of nitrogen and phosphorus excretion and ammonia emission-Review. Asian-Australasian Journal of Animal Science 12, 305-327.

Lonnerdal B, Sandberg A-S, Sandstrom B \& Kunz C (1989) Inhibitory effects of phytic acid and other inositol phosphates on zinc and calcium absorption in suckling rats. Journal of Nutrition 119, 211-214.

Lott JNA (1984) Accumulation of seed reserves of phosphorus and other minerals. In Seed Physiology, vol. 1, Development, pp. 139-166 [DR Murray, editor]. London: Academic Press.

Maenz DD \& Classen HL (1998) Phytase activity in the small intestinal brush border membrane of the chicken. Poultry Science 77, 557-563.

Maenz DD, Engele-Schann CM, Newkirk RW \& Classen HL (1999) The effect of minerals and mineral chelators on the formation of phytate-resistant and phytase-susceptible forms of phytic acid in solution and in a slurry of canola meal. Animal Feed Science and Technology 77, 177-192.

Maga JA (1982) Phytate: its chemistry, occurrence, food interactions, nutritional significance, and methods of analysis. Journal of Agricultural and Food Chemistry 30, 1-9.

Martin CJ \& Evans WJ (1986) Phytic acid-metal ion interactions. II. The effect of pH on Ca(II) binding. Journal of Inorganic Biochemistry 27, 17-30.

Mollah Y, Bryden WL, Wallis IR, Balnave D \& Annison EF (1983) Studies of low metabolisable energy wheats for poultry using conventional and rapid assay procedures and the effects of feed processing. British Poultry Science 24, $81-89$.

Mroz Z, Jongbloed AW \& Kemme P (1994) Apparent digestibility and retention of nutrients bound to phytate complexes as influenced by microbial phytase and feeding regimen in pigs. Journal of Animal Science 72, $126-132$.

Mroz Z, Jongbloed AW, Kemme PA \& Makinen M (1995a) Apparent ileal digestibility of amino acids and overall digestibility of crude protein and minerals in relation to microbial phytase and phytate levels in diets for growingfinishing pigs. Rapport ID-DLO no. 276. Leystad, The Netherlands: DLO-Institute for Animal Science and Health.

Mroz Z, Krasuki W \& Grela E (1995b) Physiological responses of lactating sows to feeding rapeseed '00' and microbial phytase. In Manipulating Pig Production, vol. 5, p. 185 [DP Hennessy and PD Cranwell, editors]. Werribee, Australasian Pig Science Association.

Namkung H \& Leeson S (1999) Effect of phytase enzyme on dietary nitrogen-corrected apparent metabolizable energy and the ileal digestibility of nitrogen and amino acids. Poultry Science 78, 1317-1319.

Nelson TS (1967) The utilization of phytate phosphorus by the chick-a review. Poultry Science 46, 862-871.

Nelson TS, Shieh TR, Wodzinski RJ \& Ware JH (1968) The availability of phytate phosphorus in soyabean meal before and after treatment with a mold phytase. Poultry Science 47, 1842-1848.

Nolan KB, Duffin PA \& McWeeny DJ (1987) Effects of phytate on mineral bioavailability: In vitro studies of $\mathrm{Mg}^{2+}$, $\mathrm{Ca}^{2+}, \mathrm{Fe}^{3+}, \mathrm{Cu}^{2+}$ and $\mathrm{Zinc}^{2+}\left(\right.$ also $\left.\mathrm{Cd}^{2+}\right)$ solubilities in the presence of phytate. Journal of the Science of Food and Agriculture 40, 79-85.

Nosworthy N \& Caldwell RA (1988) The interaction of zinc(II) and phytic acid with soya bean glycinin. Journal of the Science of Food and Agriculture 44, 143-150.

Oberleas D, Muhrer ME \& O’Dell BL (1962) Effects of phytic acid on zinc availability and parakeratosis in swine. Journal of Animal Science 21, 57-61.

O'Dell BL \& de Boland A (1976) Complexation of phytate with proteins and cations in corn grain and oilseed meals. Journal of Agricultural and Food Chemistry 24, 804-808.

Officer DI \& Batterham ES (1992a) Enzyme supplementation of Linola ${ }^{\mathrm{TM}}$ meal for grower pigs. In Proceedings of the Australian Society of Animal Production, vol. 19, p. 288 [JZ Foot, editor]. Melbourne, Victoria: Latrobe University.

Officer DI \& Batterham ES (1992b) Enzyme supplementation of Linola ${ }^{\mathrm{TM}}$ meal. In Fourth Biennial Pig Industry Seminar, p 56. Wollongbar, NSW: Wollongbar Agricultural Institute.

Okubo K, Myers DV \& Iacobucci GA (1976) Binding of phytic acid to glycinin. Cereal Chemistry 53, 513-524.

Okubo K, Waldrop AB, Iacobucci GA \& Myers DV (1975) Preparation of low-phytate soyabean protein isolate and concentrate by ultrafiltration. Cereal Chemistry 52, 263-271.

Omosaiye O \& Cheryan M (1979) Low-phytate, full fat soy protein product by ultrafiltration of aqueous extracts of whole soyabeans. Cereal Chemistry 56, 58-62.

Phillippy BQ (1999) Susceptibility of wheat and Aspergillus niger phytases to inactivation by gastrointestinal enzymes. Journal of Agricultural and Food Chemistry 47, 1385-1388.

Porres JM, Stahl CH, Cheng WH, Fu Y, Roneker KR, Pond WG \& Lei XG (1999) Dietary intrinsic phytate protects colon from lipid peroxidation in pigs with a moderately high dietary iron intake. Proceedings of the Society for Experimental Biology and Medicine 221, 80-86.

Prattley CA \& Stanley DW (1982) Protein-phytate interactions in soyabeans. I. Localisation of phytate in protein bodies and globoids. Journal of Food Biochemistry 6, 243-253. 
Prattley CA, Stanley DW \& van der Voort FR (1982) Protein-phytate interactions in soyabeans. II. Mechanism of protein-phytate binding as affected by calcium. Journal of Food Biochemistry 6, 255-271.

Rajendran S \& Prakash V (1993) Kinetics and thermodynamics of the mechanism of interaction of sodium phytate with $\alpha$-globulin. Biochemistry 32, 3474-3478.

Ravindran V (1995) Phytases in poultry nutrition. An overview. Proceedings of the Australian Poultry Science Symposium, vol. 7, pp. 135-139 [D Balnave, editor]. Sydney, NSW Poultry Research Foundation and The World's Poultry Science Association.

Ravindran V \& Bryden WL (1999) Amino acid availability in poultry-in vitro and in vivo measurements. Australian Journal of Agricultural Research 50, 889-908.

Ravindran V, Bryden WL \& Kornegay ET (1995) Phytates: occurrence, bioavailability and implications in poultry nutrition. Poultry and Avian Biology Reviews 6, 125-143.

Ravindran V, Cabahug S, Ravindran G \& Bryden WL (1999a) Influence of microbial phytase on apparent ileal amino acid digestibility in feedstuffs for broilers. Poultry Science 78, 699-706.

Ravindran V, Cabahug S, Selle PH \& Bryden WL (2000a) Response of broiler chickens to microbial phytase supplementation as influenced by dietary phytic acid and non-phytate phosphorus levels. II. Effects on apparent metabolisable energy, nutrient digestibility and nutrient retention. British Poultry Science 41, 193-200.

Ravindran V, Hew LI, Ravindran G \& Bryden WL (1999b). A comparison of ileal digesta and excreta analysis for the determination of amino acid digestibility in food ingredients for poultry. British Poultry Science 40, 266-274.

Ravindran V, Selle PH \& Bryden WL (1999c) Effects of phytase supplementation, individually and in combination, with glycanase on the nutritive value of wheat and barley. Poultry Science 78, 1588-1595.

Ravindran V, Selle PH, Ravindran G, Morel PCH, Kies AK \& Bryden WL (2000b) Microbial phytase improves performance, metabolizable energy and ileal amino acid digestibility of broilers fed a lysine-deficient diet. Poultry Science 79 (In the Press).

Reddy NR, Sathe SK \& Pierson MD (1988) Removal of phytate from great northern beans (Phaseolus vulgaris L.). Journal of Food Science 53, 107-147.

Reddy NR, Sathe SK \& Salunkhe DK (1982) Phytates in legumes and cereals. Advances in Food Research 28, 1-91.

Rojas SW \& Scott ML (1969) Factors affecting the nutritive value of cottonseed meal as a protein source in chick diets. Poultry Science 48, 819-835.

Rutherfurd SM, Edwards ACE \& Selle PH (1997) Effect of phytase on lysine-rice pollard complexes. In Manipulating Pig Production, vol. 6, p. 248 [PD Cranwell, editor]. Werribee, Victoria: Australasian Pig Science Association.

Rutherfurd SM \& Moughan PJ (1997) The Effect of Phytase on the in vitro Nitrogen and Amino Acid Digestibility and Availability of Supplemented Amino Acids in Six Pig Diets. Palmerston North, New Zealand: Monogastric Research Centre, Massey University.

Sandstead HH (1992) Fiber, phytates and mineral nutrition. Nutrition Reviews 50, 30-31.

Sauer W, Dugan M, de Lange K, Imbeah M \& Mogenthin R (1989) Considerations in methodology for the determination of amino acid digestibilities in feedstuffs for pigs. In Absorption and Utilization of Amino Acids, vol. 3, pp. 217-230 [M Friedman, editor]. Boca Raton, FL: CRC Press.

Sauer WC \& Ozimek L (1986) Digestibility of amino acids in swine: results and their practical applications. A review. Livestock Production Science 15, 367-388.

Sebastian S, Touchburn SP, Chavez ER \& Lague PC (1997) Apparent digestibility of protein and amino acids in broiler chickens fed a corn-soyabean diet supplemented with microbial phytase. Poultry Science 76, 1760-1769.

Selle PH, Ravindran V, Pittolo PH \& Bryden WL (1999) An evaluation of microbial phytase in sorghum-based broiler diets. Proceedings of the Australian Poultry Science Symposium, vol. 11, pp. 97-100 [DJ Farrell, editor]. Sydney NSW: Poultry Research Foundation and The World's Poultry Science Association.

Shamsuddin AM (1999) Metabolism and cellular functions of IP6: a review. Anticancer Research 19, 3733-3736.

Sharma CB, Goel M \& Irshad M (1978) Myoinositol hexaphosphate as a potential inhibitor of $\alpha$-amylases. Phytochemistry 17, 201-204.

Simons PCM, Versteegh HAJ, Jongbloed AW, Kemme PA, Slump P, Bos KD, Wolters MGE, Beudeker RF \& Verschoor GJ (1990) Improvement of phosphorus availability by microbial phytase in broilers and pigs. British Journal of Nutrition 64, 525-540.

Singh M \& Krikorian AD (1982) Inhibition of trypsin activity by phytate. Journal of Agricultural and Food Chemistry 30, 799-800.

Siriwan P, Bryden WL \& Annison EF (1994) Use of guanidated dietary protein to measure losses of endogenous amino acids in poultry. British Journal of Nutrition 71, 515-529.

Smith AK \& Rackis JJ (1957) Phytin elimination in soyabean protein isolation. Journal of the American Chemical Society 79, 633-637.

Taylor TG (1965) The availability of the calcium and phosphorus of plant materials for animals. Proceedings of the Nutrition Society 24, 105-111.

Taverner MR, Hume ID \& Farrell DJ (1981) Availability to pigs of amino acids in cereal grains. I. Endogenous levels of amino acids in the ileal digesta and faeces of pigs given cereal diets. British Journal of Nutrition 46, $149-158$.

Thompson LU (1988) Antinutrients and blood glucose. Food Technology 42, 123-131.

Thompson LU \& Yoon JH (1984) Starch digestibility as affected by polyphenols and phytic acid. Journal of Food Science 49, 1228-1229. 
Torre M, Rodriguez AR \& Saura-Calixto F (1991) Effects of dietary fiber and phytic acid on mineral availability. Critical Reviews in Food Science and Nutrition 1, 1-22.

Turk M, Sandberg A-S, Carlsson N-G \& Andlid T (2000) Inositol hexaphosphate hydrolysis by baker's yeast. Capacity, kinetics and degradation products. Journal of Agricultural and Food Chemistry 48, 100-104.

Vaintraub IA \& Bulmaga VP (1991) Effect of phytate on the in vitro activity of digestive proteinases. Journal of Agricultural and Food Chemistry 39, 859-861.

van der Klis JD \& Versteegh HAJ (1991) Ileal absorption of phosphorus in lightweight white laying hens using microbial phytase and various calcium contents in laying hen feed. Spelderholt Publication no. 563. Beekbergen, The Netherlands: Spelderholt Centre for Poultry Research and Information Services, DLO-Institute for Animal Science and Health.

Walker ARP \& Walker BF (1992) Fiber, phytic acid and mineral metabolism. Nutrition Reviews 50, $246-247$.

Weremko D, Fandrejewski H, Zebrowska T, Han K, Kim JH \& Cho WT (1997) Bioavailability of phosphorus in feeds of plant origin for pigs. Review. Asian-Australasian Journal of Animal Science 10, 551-556.

Wise A (1983) Dietary factors determining the biological activity of phytates. Nutrition Abstracts and Reviews in Clinical Nutrition 53, 791-806.

Wodzinski RJ \& Ullah AHJ (1996) Phytase. Advances in Applied Microbiology 42, 263-303.

Yi Z \& Kornegay ET (1996) Sites of phytase activity in the gastrointestinal tract of young pigs. Animal Feed Science and Technology 61, 361-368.

Yi Z, Kornegay ET \& Denbow DM (1996) Effect of microbial phytase on nitrogen and amino acid digestibility and nitrogen retention of turkey poults fed corn-soyabean meal diets. Poultry Science 75, 979-990.

Zebrowska T, Low AG \& Zebrowska H (1983). Studies on gastric digestion of protein and carbohydrate, gastric and exocrine pancreatic secretion in the growing pig. British Journal of Nutrition 49, 401-410.

Zhang X, Roland DA, McDaniel GR \& Rao SK (1999) Effect of Natuphos ${ }^{\complement}$ phytase supplementation to feed on performance and ileal digestibility of protein and amino acids in broilers. Poultry Science 78, 1567-1572.

Zhang ZB, Kornegay ET \& Denbow DM (1999) Evaluation of phytase and non-starch polysaccharide (NSP) enzymes added alone and in combination on nutrient utilization of individual and mixtures of feedstuffs with adult cecectomized roosters. Poultry Science 78, Suppl. 1, 73 Abstr.

Zyla K (1993) The role of acid phosphatase activity during enzymic dephosphorylation of phytates by Aspergillus niger phytase. World Journal of Microbiology and Biotechnology 9, 117-119.

Zyla K, Gogol D, Koreleski J, Swiatkiewicz S \& Ledoux DR (1999) Simultaneous application of phytase and xylanase to broiler feeds based on wheat: feeding experiment with growing broilers. Journal of the Science of Food and Agriculture 79, 1841-1848.

Zyla K, Koreleski J, Swiatkiewicz S, Wikiera A, Kujawski M, Piironen J \& Ledoux DR (2000) Effects of phosphorolytic and cell wall degrading enzymes on the performance of growing broilers fed wheat-based diets containing different calcium levels. Poultry Science 79, 66-76. 